Ann. Biol. anim. Bioch. Biophys., 1978, 18 (2 B), 377-382.

\title{
Meiotic disturbances related to human male sterility
}

by J. M. LUCIANI, A. STAHL

Laboratoire d'Histologie ef Embryologie II. Faculté de Médecine, 27, boulevard Jean-Moulin, 13385 Marseille Cedex 4, France.

Summary. The authors found an abnormal karyotype in 5 to 15 p. 100 of the cases of male sterility studied. There was a close correlation between the frequency of chromosomic abnormalities and the degree of oligospermy. Most of these abnormalities concerned the sex chromosomes, but the frequency of some robertsonian and reciprocal translocations was higher than that of the general population. It was not known why a chromosomal abnormality altered spermatogenesis. The expression of these abnormalities, especially translocations, was very diversified, ranging from normal fertility to total sterility with severe oligospermy or azoospermy.

In a small number of cases (about 5 p. 100), various meiotic abnormalities were found in sterile subjects with a normal somatic karyotype. These abnormalities were characterized by a high frequency of polyploid cells, related abnormalities and a smaller number of chiasmas, degeneration and a high frequency of univalent $X$ and $Y$ chromosomes during metaphase I. Although their origin was unknown, some abnormalities, chiasmatic in character, probably represented the first example of a meiotic mutant owing to an inbreeding factor in two azoospermic subjects.

It has been well-established in the last few years that chromosomal anomalies are one cause of human male sterility. These anomalies act in different ways :

- They may cause a reduction in fertility by forming gametes containing a genetically unbalanced genome.

- Their result may be the more or less early elimination of chromosomally unbalanced zygotes.

- They may act directly on the number of gametes formed by disruption of the meiotic process, thus leading to oligospermia or azoospermia.

Such structural and numerical abnormalities affect the sex chromosomes as well as the autosomes. In patients consulting for sterility, their frequency is generally considered between 5 and 15 p. 100 (Dutrillaux et al., 1971 ; Kjessler, 1972 ; Luciani ef al., 1972 ; Laurent ef al., 1973 ; Koulischer and Schoysman, 1974). This frequency is clearly greater than that observed in the general adult population. Moreover, Kjessler (1972) has shown the tight correlation that exists between the frequency of chromosomal anomalies and the degree of oligospermia. However, it is not always possible to determine whether a given anomaly is responsible for the sterility. Consequently, 
rather than discussing the role of each anomaly, we would like to consider in more detail three groups : males with Klinefelter's syndrome, 47, XYY patients and those males with autosomal anomalies.

Aside from these mitotic aberrations, which are represented during meiosis as specific morphological anomalies, a small percentage of cases presents isolated meiotic alterations. The latter, essentially characterized by anomalies of pairing and chiasmata counts, are probably linked to gene disorders, as suggested by the observations of Hulten and Lindsten (1973) who noted the presence of consanguinity.

\section{Fertility in males with abnormal chromosome constitution.}

1. Klinefelter's syndrome. - The role of certain gonosomal anomalies in relation to sterility is easy to understand due to the widespread tesficular damage which occurs. This is notably the case in Klinefelter's syndrome where the atrophic and hyalinized seminiferous tubules contain practically only Sertoli cells. Scattered elements of the germ line can be observed but their development does not extend beyond the stage of first spermatocyte. Sometimes, testicular damage is less marked and in such cases more developed meiotic figures are seen. This has been observed in cases of 46 , $X Y / 47, X X Y$ mosaicism (Kjessler, 1966 ; Luciani et al., 1970 ; Laurent et al., 1973) but also in the pure 47, XXY constitution (Skakkebaek et al., 1969 ; Dutrillaux et al., 1971). It is generally the $46, X Y$ cells which undergo meiosis leading to formation of a few spermatozoa. Nevertheless, the 47, XXY cells may also enter meiosis and develop up to completion of the process as shown by Skakkebaek ef al. (1969). Thus, the sterility of Klinefelter's syndrome seems to be linked more to testicular damage than to disruption of meiosis per se.

2. 47, XYY males. - Although an XYY constitution is compatible with fertility, the reason for some cases being fertile while others present reduced fertility is unknown. The testicular damage, even though of variable degree, appears almost universal in XYY syndromes (Noel ef al., 1972 ; Skakkebaek ef al., 1973a). However, few $X Y Y$ subjects are detected in sterility consultations despite the frequency of the syndrome in the overall population (1.1 p. 100 of male births). An XYY constitution was rarely found during systematic chromosome screening in sterile men (Laurent et al., 1973 ; Millef et al., 1975 ; unpublished personal data). The 47, XYY karyotyp thus seems to have little effect on gametogenesis. Meiotic studies show that most primary spermatocytes examined at diakinesis and first metaphase present a normal constitution (for review see Hulten and Pearson, 1971). The demonstration of $X Y / X Y Y$ mosaics in the spermatogonia of subjects with a $47, X Y Y$ somatic karyotype suggests that the supernumerary $Y$ chromosome is lost during spermatogonial divisions. The mechanism of this return to normal chromosome number is quite unknown; it could explain the rather mild effects of the $X Y Y$ constitution on spermatogenesis. Nevertheless, Hulten and Pearson (1971), in particular, clearly showed that a high percentage of XYY cells are capable of entering meiosis and developing up to spermatozoa with the presence of $2 Y$ bodies. Although there is almost constant testicular damage of varying degrees, spermatogenesis in $X Y Y$ males seems little disturbed, even when primary $X Y Y$ spermatocytes are examined on cytological preparations. 
3. Autosomal anomalies. - The role of autosomal anomalies, in particular the translocations, is difficult to explain despite their obvious relation since they are ten times more frequent in sterile subjects than in the general population. The balanced translocations, especially those of the robertsonian type, are not rare in the overall population: Most translocation carriers are fertile and it is only following birth of a malformed infant or after systematic screening that these are detected. Expression of translocations is highly unpredictable, varying from normal fertility to total sterility with severe oligospermia or azoospermia. Relative infertility due to spontaneous abortions may also be observed, as recently demonstrated by Sinet ef al. (1973) and Boué and Boué $(1973,1975)$. In a large proportion of cases spermatogenesis does not seem to be especially affected by the presence of a rearrangement. Nevertheless, fertility may be decreased as a consequence of the production of gametes carrying a genetically unbalanced genome leading to repeated miscarriage, stillbirth or infant death.

To illustrate this point, we present the case of a sterile carrier for a $D / D$ translocation whose meiotic profile has been published previously (Luciani ef al., 1972). The father of the subject, who was also a carrier for the same translocation, fathered three children including the patient, and apparently presented no reduction in fertility. An analogous observation was reported by Chandley ef al. (1972) in $13 \mathrm{q} 14 \mathrm{q}$ familial translocation heterozygosity. Some of the carriers of $13 \mathrm{q} 14 \mathrm{q}$ translocation showed high abortion rates, while others appeared not to do so. At present, there is no explanation for these variations and caution is necessary in judging the role of translocations in the breakdown of spermatogenesis.

This same variability of expression is also observed for reciprocal translocations in the heterozygous state. Chandley et al. (1976) recently reported 5 cases of reciprocal translocations. Four of the five patients were clinically subfertile (childless or miscarriages) while testicular histology and spermatogenic activity were normal. In the remaining case, azoospermia was observed with deficiency in the later stages of spermatogenesis. Thus, as in drosophila and the mouse, structural rearrangements in man may be associated with spermatogenic failure yielding primary sterility. The effects of such translocations are generally manifested during the later stages of spermatogenesis. The reasons for the reciprocal translocations disrupting spermatogenesis have been analysed in detail by Chandley ef al. (1972). Nevertheless, it is still difficult to understand why certain translocations are associated with spermatogenic failure while others are not.

\section{Fertility in males with normal chromosome constitution.}

In subjects with normal karyotypes but azoospermia, different meiotic anomalies have been found in a small percentage of case (Koulischer and Schoysman, 1974 : 2 p. 100 ; Koueke, $1975: 5$ p. 100). Among these anomalies are polyploid cells, abnormal pairing, reduced number of chiasmata, degenerative images and dissociation of the $X$ and $Y$ chromosomes during first metaphase. As a general rule, the result of these anomalies is a spermatogenic arrest at either pachytene or a later stage.

1. Polyploidy. - The existence of polyploid cells in human meiosis was first reported by Darlington and Haque in 1962. A certain degree of polyploidy may be 
seen in normal individuals but the percentage of cells is low : between 1 p. 100 and 7 p. 100 according to the authors (Luciani, 1970). Percentages greater than 10 p. 100 can be considered pathological. The only observation of a highly increased proportion of polyploid primary spermatocytes ( 40 p. 100) was reported in 1969 by de Grouchy and Lumbroso in a case of excretory infertility.

2. Synaptic and chiasmatic anomalies. - The first cases of low chiasma counts were reported by Hulten et al. (1970) and Pearson et al. (1970). Since then, this anomaly has been regularly found during meiotic exploration in sterile subjects (Skakkebaek ef al., $1973 b$; Ferguson-Smith 1974 ; Chaganti and German, 1974 ; Koulischer ef al., 1975 ; Koueke, 1975). The cause of the low chiasma frequency was believed to be an impaired or delayed pairing of the homologous chromosomes at pachytene. Indeed, Hulten et al. (1974) observed abnormal synaptonemal complex in an oligochiasmatic man with spermatogenic arrest. This condition probably represents the first example of a meiotic mutant in man since two of these azoospermic men examined by Hulten and Lindsten (1973) were the product of consanguinous marriages.

3. Decreased number of interstitial chiasmata. - This rarely isolated anomaly was first observed by Dutrillaux and Gueguen (1971) : the number of interstitial chiasmata was 7 per cell, whereas normally it is approximately 11 (Luciani, 1970). In certain subjects the number of interstitial chiasmata may be very low, less than 5 (Koueke, 1975). In such cases, the anomaly is associated with a decrease in the total chiasma counts.

4. Degenerative figures. - Degenerative figures involving in particular primary spermatocytes at diakinesis and metaphase are observed with a more or less high frequency. The deg ree of degeneration is variable, ranging from simple modification of bivalent form up to the presence of fuzzy blocks resulting from fusion of several bivalents. Such degenerative images are often associated with anomalies of synapsis and chiasmata and may, in these cases, be interpreted as the consequence of such anomalies which appeared early on in the course of meiosis. On the other hand, when the degenerative figures are isolated, it is impossible to determine whether the chromosomal damage is primary and thus responsible for the sterility, or rather the morphological translation of cellular and testicular lesions.

5. Dissociation of $X$ and $Y$ chromosomes. - Normally, the $X$ and $Y$ chromosomes are in end-to-end association during diakinesis and first meiotic metaphase. In a certain number of nuclei, however, these chromosomes are separated and present as two univalents. The proportion of $X$ and $Y$ univalents largely depends on technical considerations (Luciani, 1970). Despite the large variations according to author, $X-Y$ dissociation can be considered normal when less than 30 p. 100 . Koveke (1975) reported 3 cases of an increased percentage of sex chromosome univalents (about 50 p. 100) associated with severe oligospermia or azoospermia. Chandley (1973) and Ferguson-Smith (1974) previously demonstrated the presence of maturation arrest in cases of sex chromosome univalents. Until recently, the only cases of complete absence of $X-Y$ association were observed in the mouse by Cattanach et al. (1968) and Beechey (1973). This failure of $X-Y$ association was accompanied by spermatogenic arrest : no spermatids or spermatozoa were seen. Similar failure of $X-Y$ asso- 
ciation in meiosis has been described in two azoospermic human males, one with a dicentric $Y$ chromosome (Mc Ilree et al., 1966) and one with a ring $Y$ chromosome (Chandley and Edmond, 1971).

Thus, detailed studies of infertile men might reveal the possibility of meiotic mutants affecting chromosome pairing, chiasma formation and sex chromosome association.

In conclusion, although there is strong evidence suggesting that a given chromosome abnormality may be a cause of infertility, it is presently impossible to resolve this question with certainty.

$27^{\mathrm{e}}$ Congrès international des Sciences physiologiques, Symposium "Germ and somatic cell interaction " Paris, 21-23 juillet 1977.

Résumé. La fréquence avec laquelle un caryotype anormal est observé dans les cas de stérilité masculine varie de 5 p. 100 à 15 p. 100 selon les auteurs. Une étroite corrélation existe entre la fréquence des anomalies chromosomiques et le degré de l'oligospermie. La majorité de ces anomalies intéresse les chromosomes sexuels mais un certain nombre de translocations roberstsoniennes et réciproques peuvent être observées avec une fréquence supérieure à celle de la population générale. La raison pour laquelle une anomalie chromosomique est responsable d'une altération de la spermatogenèse n'est pas connue avec certitude. En effet, le mode d'expression de ces anomalies, en particulier les translocations, est des plus variables allant d'une fécondité normale à une stérilité totale avec oligospermie sévère ou azoospermie.

Dans un faible pourcentage de cas, environ 5 p. 100, diverses anomailes méiotiques ont été observées chez les sujets stériles ayant un caryotype somatique normal. Ces anomalies sont représentées par une fréquence élevée de cellules polyploïdes, des anomalies d'appariement et une réduction du nombre des chiasmas, des images dégénératives et une fréquence élevée de chromosomes $X$ et $Y$ univalents au cours de la méłaphase $I$. Bien que l'origine de ces anomalies soit inconnue, certaines d'entre elles, et notamment les anomalies chiasmatiques, représentent probablement le premier exemple d'un mutant méiotique en raison de l'existence d'un facteur de consanguinité retrouvé chez deux sujets azoospermiques.

\section{References}

BEECHEY C. V., 1973. X-Y chromosome dissociation and sterility in the mouse. Cytogenet. Cell. Genet., 12, 60-67.

BOUÉ J., BOUÉ A., 1973. Anomalies chromosomiques dans les avortements spontanés, 29-53. In BOUÉ A., THIBAULT C., Les Accidents chromosomiques de la reproduction. Coll. INSERM, Paris.

BOUÉ J., BOUÉ A., 1975. Ełudes prospectives des facteurs chromosomiques de qualité des gamètes. Ann. Biol. anim. Bioch. Biophys., 15, 757-763.

CATTANACH B. M., POLLARD C. E., ISAACSON J. H., 1968. Ethyl methanesulfonate-induced chromosome breakage in the mouse. Mutat. Res., 6, 297-307.

CHAGANTI R. S. K., GERMAN J., 1974. Human male infertility, probably genetically determined, due to a defective meiotic pairing and chiasma formation. Am. J. hum. Genet., 26, $19 \mathrm{~A}$.

CHANDLEY A. C., 1973. Univalent sex chromosomes and meiotic arrest in man. Heredity, 30, 262.

CHANDLEY A. C., EDMOND P., 1971. Meiotic studies on a subfertile patient with a ring Y chromosome. Cytogenetics, 10, 295-304.

CHANDLEY A. C., CHRISTIE S., FLETCHER J., FRACKIEWICZ A., JACOBS P. A., 1972. Translocation heterozygosity and associated subfertility in man. Cytogenetics, 11, 516-533.

CHANDLEY A. C., SEUANEZ H., FLETCHER J. M., 1976. Meiotic behavior of five human reciprocal translocations. Cylogenet. Cell Genet., 17, 98-111.

DARLINGTON C. D., HAQUE A., 1962. Polyploidy with chromosome breakage at meiosis in the human male. Cytogenetics, 1, 196-198. 
DUTRILLAUX B., LE LORIER G., SALAT J., ROTMAN J., 1971. Incidence des anomalies chromosomiques dans la stérilité masculine. A propos d'une étude de 40 cas. Presse méd., 79, 12311234.

DUTRILLAUX B., GUEGUEN J., 1971. Anomalies méiotiques et gamétiques multiples dans un cas de stérilité masculine. Ann. Génét., 14, 49-52.

FERGUSON-SMITH M. A., 1974. Meiosis in the human male, 33-41. In PEARSON P. L., LEWIS K. R., Chromosomes Today, Vol. 5, J. Wiley and Sons, N.-Y., Toronto, Israël Univ. Press, Jerusalem.

GROUCHY J. de, LUMBROSO P., 1969. Fréquence élevée de spermatocyłes primaires avec $2 \mathrm{~N}$ tétrades dans une biopsie testiculaire. Ann. Génét., 12, 65-66.

HULTEN M., ELIASSON R., TILLINGER K. G., 1970. Low chiasma count and other meiotic irregularities in two infertile 46, XY men with spermatogenic arrest. Hereditas, 65, 285-290.

HULTEN M., PEARSON P., 1971. Fluorescent evidence for spermatocytes with two $Y$ chromosomes in an XYY male. Ann. hum. Genet., 34, 273-276.

HULTEN M., LINDSTEN J., 1973. Cytogenetic aspects of human male meiosis, 327-387. In HARRIS H., HIRSCHHORN K., Adv. Hum. Genet., vol. 4, Plenum Press, N.-Y., London.

HULTEN M., SOLARI A. J., SKAKKEBAEK N. E., 1974. Abnormal synaptonemal complex in an oligochiasmatic man with spermatogenic arrest. Hereditas, 78, 105-116.

KJESSLER B., 1966. Karyotype meiosis and spermatogenesis in a sample of men attending an infertility clinic. Monographs on Human Genetics, 2, Karger, Basel.

KJESSLER B., 1972. Facteurs génétiques dans la subfertilité mâle humaine, 205-225. In THIBAULT C., Fécondité et stérilité du mâle. Acquisitions récentes. Masson, Paris.

KOUEKE P., 1975. Incidence des anomalies génétiques dans la stérilité masculine. Elude méiotique de 100 cas. Diplôme d'Ełudes et de Recherches en Biologie Humaine, Marseille, 36 pp.

KOULISCHER L., SCHOYSMAN R., 1974. Chromosomes and human infertility. I. Mitotic and meiotic chromosome studies in 202 consecutive male patients. Clin. Genet., 5, 116-126.

KOULISCHER L., SCHOYSMAN R., VAN DE CASSEYE M., 1975. Meiosis in human male sterility : report of 27 cases with a common anomaly. Clin. Genet., 8, 396.

LAURENT C., PAPATHANASSIOU Z., HAOUR B., COGNAT M., 1973. Ełude mitotique et méiotique de 70 cas de stérilité masculine. Andrologie, 5, 193-200.

LUCIANI J. M., 1970. Les chromosomes méiotiques de l'homme. II. Le nucléole, les chiasmas. III. La stérilité masculine. Ann. Génét., 13, 169-182.

LUCIANI J. M., MATTÉl A., DEVICTOR-VUILLET M., RUBIN Ph., STAHL A., VAGUE J., 1970. Ełude des chromosomes méiotiques dans un cas de maladie de Klinefelter avec spermatogenèse et caryotype 46, XY/47, XXY. Ann. Génét., 13, 249-253.

LUCIANंI J. M., MATTÉl A., STAHL A., 1972. La méiose dans les stérilités masculines, 189-197. In THIBAULT C., Fécondité ef stérilité du mâle. Acquisitions récentes. Masson, Paris.

MCILREE M. E., PRICE W. H., COURT-BROWN W. M., TULLOCH W. S., NEWSAM J. E., MCLEAN N. 1966. Chromosome studies on the testicular cells from 50 subfertile men. Lancet, 2, 69-71.

MILLET D., PLACHOT M., LETY M. A., GROUCHY J. de, NETTER A., 1975. Les remaniements chromosomiques dans la stérilité masculine. J. Gyn. Obst. Biol. Reprod., 4, 689-701.

NOEL B., LUCIANI J. M., BENEZECH M., QUACK B., 1972. Polymorphisme de la disomie Y. Gaz. Med. Fr., 79, 7047-7076.

PEARSON P. L., ELLIS J. D., EVANS H. J., 1970. A gross reduction in chiasma formation during meiotic prophase and a defective DNA repair mechanism associated with a case of human male infertility. Cytogenetics, 9, 460-467.

SINET P. M., DUTRILLAUX B., PRIEUR M., LEJEUNE J., 1973. Rôle des transiocations parentales en cas de fausses couches à répétition. Rev. fr. Gynéc., 68, 655-660.

SKAKKEBAEK N. E., PHILIP J., HAMMEN R., 1969. Meiotic chromosomes in Klinefelfer's syndrome. Nature, 221, 1075-1076.

SKAKKEBAEK N. E., ZEUTHEN E., NIELSEN J., YDE H., 1973a. Abnormal spermatogenesis in $X Y Y$ males : a report of 4 cases ascertained through a population study. Fert. Ster., 24, 390-396.

SKAKKEBAEK M. E., BRYANT J. I. PHILIP J., 1973b. Studies on meiotic chromosomes in infertile men and controls with normal karyotypes. J. Reprod. Fertil., 35, 23-36. 